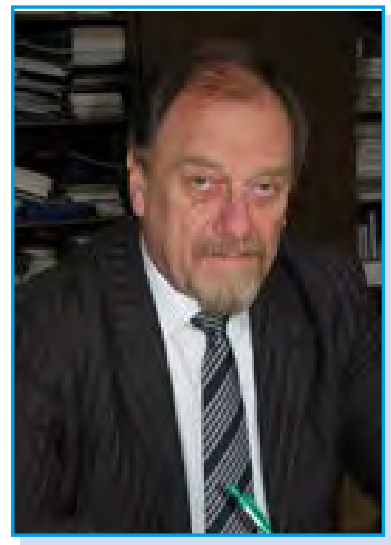

Олександр Ляшенко - доктор педагогічних наук, професор, дійсний член НАПН України, академік-секретар відділення загальної середньої освіти НАПН України, м. Київ, Україна.

Коло наукових інтересів: проблеми стандартизації освіти, модернізація змісту загальної середньої освіти, теорія і методика навчання фізики.

o.liashenko@gmail.com

https://orcid.org/0000-0001-6885-5978

доктор педагогічних наук, професор, дійсний член (академік) НАПН Украӥни, віцепрезидент НАПН України, директор Інституту педагогіки НАПН України, м. Київ, Україна.

Коло наукових інтересів: теорія і методологія організації освітнього процесу в закладах загальної середньої освіти, методика навчання географії.

proftop@ukr.net

https://orcid.org/0000-0001-7690-1663

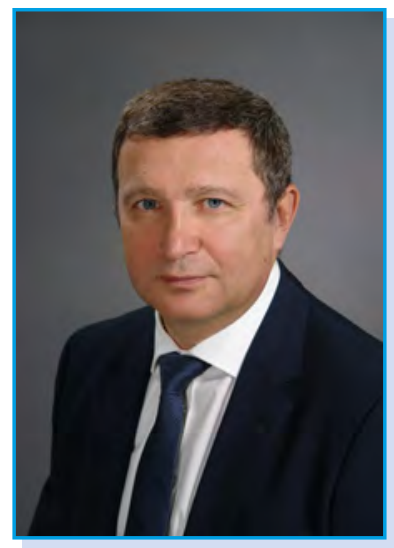

УДК373.5.011.33:005.591.6

https://doi.org/10.32405/2411-1317-2021-4-29-36

\title{
НАУКОВИЙ СУПРОВІД МОДЕРНІЗАЦІї ЗМІСТУ БАЗОВОЇ СЕРЕДНЬОЇ ОСВІТИ: ПРОБЛЕМИ І ВИКЛИКИ
}

У статті розглядаються наукові засади оновлення і структурування змісту базової середньої освіти, покладені в основу нещодавно прийнятого Державного стандарту базової середньої освіти та розробленої Типової освітньої програми для 5-9 класів закладів загальної середньої освіти. На підставі аналізу різних підходів до добору змісту шкільної освіти в різні історичні часи представлена методологія дослідження, яка грунтується на єдності особистісно орієнтованого, діяльнісного і компетентнісного підходів до навчання як фундаменту сучасної парадигми освіти. Показана відмінність у структуруванні змісту освіти, що грунтується на теорії змісту, яка властива вітчизняній традиції, та теорій курикулуму, що використовуються у зарубіжній освітній практиці. Розкрито компетентнісні засади модернізації змісту освіти, покладені в основу нового стандарту базової середньої освіти, обгрунтовано доцільність переходу від знаннєвої парадигми освіти до компетентнісної в умовах нинішнього оновлення змісту освіти. Підкреслюється, що нинішня модернізація змісту освіти передбачає ширше використання предметноінтегрованого підходу до структурування навчального матеріалу, який враховує вікові особливості психічного розвитку дитини. 
Ключові слова: базова середня освіта, модернізація змісту освіти, теорія змісту освіти, компетентнісний підхід до навчання, структурування змісту освіти, інтеграція знань.

Постановка проблеми. Після затвердження Державного стандарту базової середньої освіти (Державний стандарт, 2020) та типових освітніх програм для 5-9 класів закладів загальної середньої освіти (Типова освітня програма, 2021) розпочинається черговий етап реформування загальної середньої освіти. На цьому етапі продовжується реформа шкільної освіти, розпочата у 2018 р. у початковій школі відповідно до концепції «Нова українська школа» (Концепція, 2016). Наступність початкової і базової середньої освіти проявляється насамперед продовженні формування ключових і предметних компетентностей та наскрізних умінь, необхідних для свідомого вибору учнями подальшого життєвого шляху та самореалізації, навчання на рівні профільної освіти або здобуття професії. Специфічним для цього рівня середньої освіти є більш глибока диференціація змісту за предметними галузями з урахуванням інтересів та обдарувань учнів. Тому на рівні базової середньої освіти проблема структуризації змісту набуває пріоритетного значення, особливо у 7-9 класах.

Трансформаційні процеси, що відбуваються в освітній практиці у зв’язку з реформуванням української школи, вимагають належного теоретичного обгрунтування і науково-методичного супроводу. У цьому зв'язку природніми постають питання: 1) чи відповідає теоретичне підгрунтя освітніх наук запитам нинішньої освітянської практики?; 2) чи спроможні вони здійснити методологічне і дидактико-методичне забезпечення тих трансформаційних процесів, що відбуваються в освітній практиці?; 3) переосмислення яких теоретичних засад потребують освітні науки відповідно до нової парадигми освіти?

Ці питання не риторичні. Сенс їх у тому, щоб з’ясувати й окреслити зміни в теорії навчання, які б відповідали запитам освітньої практики для дієвого наукового супроводу реформи української школи. Відповіді на них вимагають грунтовного аналізу, який за глибиною й обсягом висвітлення проблем виходять за межі одного повідомлення. Тому в цій статті автори зосередили увагу лише на тих викликах, що пов'язані з оновленням змісту базової середньої освіти.

Мета статті полягає у висвітленні наукових засад відбору і структурування змісту базової середньої освіти на основі прийнятого державного стандарту освіти відповідного рівня та типової освітньої програми для 5-9 класів закладів загальної середньої освіти.

Аналіз останніх досліджень і публікацій. Проблема обгрунтування змісту освіту має багату традицію пошуків. Історично складалося так, що спочатку зміст навчання обмежувався набором умінь і навичок, потрібних для певного ремесла. Потім педагоги почали вважати, що в процесі навчання здобувачам освіти необхідно передати якомога більший обсяг знань із різних наук, засвоєння яких сприятиме розвитку дитини (енциклопедизм Я. Коменського). Згодом пріоритет надавався не знаннєвим структурам, а розвитку мислення (дидактичний формалізм Ж. Піаже). Далі, на основі дидактичного утилітаризму Дж. Д’юї запропонував вибудовувати освітній процес на соціально детермінованих видах діяльності, якими повинні оволодіти учні в навчальному процесі. У дидактичному обгрунтуванні змісту освіти мали місце й інші течії відбору навчального матеріалу.

У вітчизняній педагогіці радянського періоду відносно завершеного вигляду в теоретичному сенсі вони набули наприкінці минулого століття в працях І. Лернера, В. Краєвського, В. Лєдньова, О. Савченко та ін. (Краевский, Лернер, 1983). В основу цієї теорії змісту освіти була покладена чотирикомпонентна структура соціального досвіду, що грунтується на взаємозв'язку змістового і процесуального компонентів навчальної діяльності учнів:

- знання про навколишню дійсність та способи діяльності інтелектуального та практичного характеру;

- досвід здійснення способів діяльності, у процесі якого формуються уміння і навички, необхідні для репродуктивної діяльності;

- досвід творчої діяльності, завдяки якому учні набувають здатності креативного мислення; 
- д досвід емоційно-ціннісного ставлення особи до дійсності, до своєї діяльності і самої себе, завдяки якому формується система цінностей і світогляд особистості.

У зарубіжній педагогічній традиції відбір і структурування змісту освіти грунтується на теоріях курикулуму, в основу яких покладалися різні засадничі принципи. Одні теорії надавали перевагу «важливим» знанням (powerful knowledge), які необхідні для успішної самореалізації особистості; інші більшу увагу приділяли досвіду соціально важливих способів діяльності, необхідних для життєдіяльності людини (learning activities \& practices). Так, один із розробників конструктивістської моделі теорії курикулуму Р. Тайлер вказує на такі чотири складники реконструкції освітнього процесу: освітні цілі, що реалізує заклад освіти; вибір досвіту освітньої діяльності, адекватний обраним цілям; проєктування освітньої діяльності для їх досягнення; оцінювання кінцевих результатів навчання, яких мають досягнути учні (Tyler, 1949). Дискусія навколо цих питань не припиняється й донині та періодично поновлюється, особливо у зв'язку із запровадженням компетентнісної моделі курикулуму (Young, 2013; Zongyi, 2015). Зокрема, найчастіше вона розгортається навколо питань, пов’язаних із обсягом базових наукових знань, необхідних у шкільному навчанні, та їх ролі у формуванні особистості з різними інтересами, потребами, здібностями.

Методологія дослідження. Оновлення змісту шкільної освіти, що відбувалося в різні часи, завжди було підпорядковано суті освітніх парадигм, що домінували на той час у професійному освітянському співтоваристві і суспільстві загалом. У процесі історичного розвитку суспільства освіта послуговувалася різними освітніми парадигмами (знаннєвою, біхевіористичною, гуманістичною, технократичною тощо), які відповідали тим чи іншим ідеям, принципам, соціокультурним цінностям чи поглядам на сутність освітнього процесу. Так, знаннєва парадигма освіти, що тривалий час панувала в недалекому минулому, була зорієнтована на формування якомога більшого обсягу різнобічних знань, оскільки вважалося, що інтелектуальний розвиток дитини значною мірою залежить від кількості і структурованості засвоєних знань. Сучасна ж парадигма освіти зміщує акцент у процесуальний бік формування навичок застосовувати набуті знання в людській практиці і розвиток особистості. Нині вагомим стає вміння здобувати необхідну інформацію для розв'язання посталих проблем у різноманітних ситуаціях життєвої практики: у навчанні, професійній діяльності, побуті тощо. Тобто провідна роль в освітньому процесі належить не стільки обсягу засвоєних знань і здатності їх відтворювати, як операціональності здобутого знання, здатності особи актуалізувати його в різних сферах життєвої практики. Такі компетентнісні засади навчання наразі відтворюють світові тенденції розвитку освітніх систем більшості країн у XXI ст.

Головним рушієм посталих змін в українській освіті є перехід теорії навчання від знаннєвої до компетентнісної парадигми освіти, що нині сповідується світовою науковою спільнотою і грунтується на єдності особистісно орієнтованого, діяльнісного і компетентнісного підходів. Це фактично ідеологічна тріада сучасної парадигми освіти, яка інтегрує в собі три відомі у педагогіці й апробовані у шкільній практиці підходи.

Особистісно орієнтований підхід, як дидактична основа освітнього процесу, орієнтує його на врахування вікових і пізнавальних особливостей розвитку дитини. Головною його ідеєю є те, що усі діти, навіть одного віку, різні за здібностями, інтересами, досвідом, мотивами навчання, устремліннями тощо. Психологічною основою освітнього процесу визнається діяльнісний підхід, завдяки якому навчання учнів організовується на конструктивній основі активної діяльності учнів із пошуку розв’язків проблем і прийняття відповідних рішень. Компетентнісний підхід це гносеологічна основа сучасної парадигми освіти, яка орієнтує освітній процес на результат навчання, на набуття здобувачами освіти ключових і предметних компетентностей шляхом особистісного досвіду життєдіяльності в різних ії формах: ігровій, навчальній, дослідницькій, творчому самовираженні, спілкуванні, праці тощо.

Вочевидь у цій тріаді підходів стосовно проєктування змісту освіти центральне місце належить компетентнісним засадам побудови освітнього процесу, орієнтації його на активну піз- 
навальну діяльність учнів та особливості їх розвитку, беручи до уваги їхні здібності, інтереси, потреби, сенситивність тощо.

Результати дослідження. У контексті парадигмальних змін, що спонукали українську середню освіту до реформування, знаходяться відповіді на питання, поставлені на початку статті. Вони мають як практичний аспект, пов'язаний із розробленням освітніх стандартів, так і теоретичний аспект, який зумовлений необхідністю обгрунтування концептуальних змін у модернізації змісту освіти (Liashenko, 2019).

Загалом добір змісту освіти відбувається на підставі означення її мети і вибору адекватної моделі навчання, що відповідає тій чи іншій парадигмі. У нинішніх умовах вони спрямовані на процес розвитку дитини, формування її особистісного знання. За таких умов освітній процес має на меті розкрити внутрішні механізми розвитку інтелекту дитини, його здатності і готовності до використання набутих знань і досвіду у різних життєвих ситуаціях (побуті, освітній чи професійній діяльності, повсякденному житті тощо), ціннісного ставлення до навколишнього світу.

Основою такого навчання $є$ визнання унікальності кожного учня як особистості і персоніфікація його освітньої траєкторії. За такої освітньої моделі учень усвідомлює знання і когнітивні вміння з притаманними саме йому сенсами і цінностями, сутнісними характеристиками й уявленнями та образами. Роль учителя у такому разі змінюється. Він стає організатором освітнього середовища, в якому учень, спираючись на свій особистий потенціал, завдяки власній діяльності і певній педагогічній технології набуває досвіду пізнання світу. Результатом такого навчання стає розвиток здібностей і обдарованості учня, які характеризують його як особистість. Знання, вміння і ставлення, сформовані в такому освітньому процесі, стають його особистісно усвідомленим досвідом, що відображається у формі набутих компетентностей (ключових, предметних, позапредметних), наскрізних умінь та світогляду. Тому в сучасному освітньому процесі усвідомлення змісту освіти відіграє роль засобу розвитку особистості, розкриття її здібностей, інтелектуального, духовного і фізичного потенціалу та не передбачає засвоєння знань з певної галузі чи набуття навичок певної діяльності як кінцеву мету навчання.

Зміст освіти спрямовується на формування ціннісних ставлень, навичок відповідальної поведінки в природі та суспільстві (Rybalko, Topuzov, Velychko, 2020).

Освітні стандарти, що нині запроваджуються в шкільну практику, відрізняються від їх попередніх генерацій (2001 р.; 2004 р.; 2011 р.) насамперед орієнтацією на ключові компетентності у структуруванні змісту. У попередніх освітніх стандартах компетентнісний підхід також мав місце. Проте основою їх побудови були предметні компетентності, які окреслювали зміст і вимоги до результатів навчання за конкретними освітніми галузями (мовно-літературною, суспільствознавчою, математичною, природознавчою, мистецькою, технологічною і фізкультурною). Відповідно, кожна з них мала перелік усталений навчальних предметів (українська мова, українська і зарубіжна література, іноземна мова, історія України і всесвітня історія, алгебра, геометрія, біологія, фізика, хімія тощо).

Новий стандарт базової середньої освіти (2020р.) будується на інших концептуальних засадах. У ньому зміст освіти окреслюється компетентнісним потенціалом освітніх галузей, який розкриває внесок кожної з них у формування відповідних ключових компетентностей. На цій основі кожна галузь характеризується конкретними результатами навчання, яких повинен досягнути здобувач освіти по завершенню певного її рівня (або циклу). Зміст кожної освітньої галузі структурується за загальними результатами і змістовими лініями, які відображають їх гносеологічну сутність. Наприклад, для природничо-наукової освітньої галузі визначальними $є$ здатність досліджувати природний світ, уміння використовувати наукові знання для пояснення природних явищ і техніко-технологічних процесів, екологічна обізнаність про наслідки людської діяльності в довкіллі, а також світоглядні цінності і ставлення до здобутого знання і набутого пізнавального досвіду.

Серед ключових компетентностей $є$ такі, що чітко пов’язані з конкретними галузями знань чи вміннями (наприклад, математична і природничо-наукова, уміння читати, писати і рахувати, 
спілкуватися рідною або іноземними мовами тощо). Тобто вони предметно зорієнтовані i, як правило, у шкільній освіті мають відповідники у вигляді навчальних предметів (математика, іноземна мова, історія, фізика тощо). Водночас серед ключових компетентностей $є$ й такі, що не мають чітко визначеного предметного відповідника, тобто їх набуття здійснюється в освітньому процесі з різних предметів і курсів (наприклад, підприємливість й інноваційність, вміння навчатися, комунікативні навички взаємодіяти з іншими тощо). Варто також розуміти, що набуття компетентностей, пов'язаних із предметними галузями знань, не обмежується лише завдяки їх знаннєвими відповідниками (навчальними предметами чи інтегрованими курсами), а відбувається комплексно, усіма освітніми галузями у шкільному навчанні, а також у позашкільній пізнавальній практиці учнів та їх життєвій практиці. Адже зміст освіти є цілісним і системним щодо формування всієї сукупності ключових компетентностей. Тому кожна освітня галузь має конкретний потенціал щодо формування кожної ключової компетентності і відповідальна тією чи іншою мірою за набуття її здобувачами освіти.

Окрім того, слід брати до уваги, що досягнення обов’язкового результату, обумовленого державним стандартом, може відбуватися у різний спосіб: шляхом «традиційного» навчання окремих предметів або завдяки інтеграції змісту з різних предметів в єдиний курс чи інші інтегровані форми освітньої діяльності. Як саме можуть реалізовуватися заплановані стандартом обов'язкові результати визначає освітня програма, яку розробляє заклад освіти відповідно до освітніх потреб та інтересів учнів. Вона може грунтуватися на типовій освітній програмі, яку розробляє Міністерство освіти і науки, або бути власною оригінальною освітньою програмою, створеною самим закладом освіти і схваленою державним органом, що згідно з законодавством відповідає за акредитацію таких програм.

Нинішня модернізація змісту освіти передбачає ширше використання предметноінтегрованого підходу до структурування навчального матеріалу. На ранніх ступенях навчання, зокрема в початковій школі, міжгалузева і міжпредметна інтеграції займає більшу частку навчального навантаження, ніж у гімназії чи ліцеї, де предметне викладання, особливо в 7-9 клаcax, $€$ переважаючим. Це зумовлено особливостями сприйняття довкілля дитиною молодшого шкільного віку, її віковими пізнавальними можливостями, сенситивними періодами ії розвитку. Адже в цьому віці світобачення дитини характеризується цілісним сприйняттям дійсності, особливо не розрізняючи в довкіллі природне і соціальне, матеріальне і духовне, кількісне і якісне.

Із часом у свідомості дитини відбувається поступова диференціація здобутих знань за певними галузями, зумовлена становленням абстрактного (понятійного) мислення особи в підлітковому віці. Тому в гімназійний період навчання (7-9 класи) повинно переважати предметне навчання, яке дає можливість викласти навчальний матеріал глибше і більш системно, відповідно до вікових особливостей розумового розвитку підлітків. Добір змісту навчання предметів здійснюється, як правило, на основі теоретичних понятійних систем (наукових теорій, систематизованих поглядів і учінь, інших логічних структур знань). Так, наприклад, у школі вивчаються природничі науки (біологія, фізика, хімія, географія). За таким же принципом курс математики поділяють на алгебру і геометрію, а у суспільнознавчих предметах виокремлюються основи правознавства тощо.

Згодом, у ліцеї, необхідність узагальнення і систематизації знань та усвідомлення загальних закономірностей навколишнього світу вимагає цілісного світосприймання, яке може здійснюватися на цьому етапі навчання завдяки тематичній і міжгалузевій інтеграції. Як правило, це відбувається у формі інтегрованих курсів або шляхом міжпредметної/міжгалузевої інтеграції знань в освітньому процесі на уроках, під час виконання навчальних проєктів, на учнівських конференціях тощо. Це не виключає предметного підходу до проєктування змісту освіти, а лише урізноманітнює методи навчання та адаптує навчальний процес до освітніх потреб здобувачів освіти.

Структуризація змісту на цьому рівні освіти зумовлена прагматичними цільовими настановами життєвого вибору учнів. Якщо набуті знання і компетентності є необхідним фундаментом професійної кваліфікації чи здобуття освіти більш високого рівня, то відповідна система знань реалізується окремим навчальним предметом, як правило, поглибленого рівня засвоєння. 
Якщо ж зміст предмета відіграє загальноосвітню чи світоглядну роль, наприклад, природничі науки для «гуманітаріїв» або суспільні для «природничників», то доцільнішим буде інтегрований підхід до навчання, завдяки якому розкривається цілісність наукового знання у поясненні феноменів довкілля і розуміння проблем навколишнього світу з позицій різних галузей знань.

Висновки. Отже, новий стандарт базової середньої освіти не регламентує ії зміст жорстко й однобічно, а лише визначає рамкові обов'язкові вимоги щодо кінцевих результатів для кожного $з$ ії рівнів (циклів). За таких умов він надає академічну свободу здобувачам освіти, учителям, закладу освіти загалом щодо вибору освітньої політики, урахування інтересів й освітніх потреб учнів та побудови на цій основі відповідної траєкторії навчання, за якою ці результати будуть досягатися. Водночас варто зазначити, що заклади освіти не готові належним чином до такої ініціативи, оскільки ніде, а ні в педагогічних університетах, а ні в системі підвищення кваліфікації освітян, такої підготовки не здійснюється.

Натомість важливою умовою досягнення цілей загальної середньої освіти є органічне поєднання освітньої програми закладу, модельних навчальних програм, які визначають очікувані результати (зміст навчання та пріоритетні види навчально-пізнавальної діяльності), навчальнометодичного забезпечення (підручники та навчальні посібники), засобів навчання та кадрового потенціалу (Топузов, Засєкіна, 2021).

В умовах сьогодення, коли згідно з чинним законодавством кожний заклад загальної середньої освіти повинен самостійно розробляти власну освітню програму, методологічні напрацювання теорії змісту освіти не завжди можуть стати в нагоді педагогічним працівникам, яким потрібні конкретні практичні рекомендації щодо створення різних варіантів освітніх програм. Тобто на часі створення практико орієнтованої теорії освітньої програми на кшталт зарубіжних теорій курикулуму, завдяки якій освітяни матимуть дієвий засіб проєктування освітнього процесу в школі.

3 цією метою, на нашу думку, у наукових колах доцільно розгорнути широку дискусію про концептуальні засади такого вчення, а також розпочати наукові пошуки методичних підходів до формування шкільних освітніх програм в умовах академічної свободи і автономії закладів загальної середньої освіти. Наразі потребує уточнення термінологічний апарат, що нині вживається в нормативно-законодавчому полі організації шкільного навчального процесу. Зокрема, це стосується однозначності у трактуванні таких базових понять, як навчальний предмет й інтегрований курс, визначення номенклатури предметів та їх групування, що відповідали б міжнародним нормам тощо. Наприклад, у типовій освітній програмі для 5-9 класів закладів загальної середньої освіти навчальний предмет «Географія» віднесено до природничої освітньої галузі, оскільки раніше традиційно акцент робився на фізичній географії, а соціальний ï компонент вивчався у старших класах. Нині ж ситуація змінилася, географія як навчальний предмет за змістом має більш соціальний контент. Це відповідає світовим тенденціям змістового наповнення цієї дисципліни, адже за міжнародною номенклатурою географія належить до соціальних студій (European Commission, 2021), а фізична географія, що є одним із ії складників, який найчастіше іменують «Навколишнє середовище» або інакше, але в контексті природного довкілля.

Не менш гострою залишається проблема запровадження інтегрованих курсів, які невиправдано і необгрунтовано звинувачують у ненауковості змісту освіти і пониженні ії якості. Інтеграція - це природній процес розвитку знання, який властивий як науковому, так і навчальному пізнанню. У науці це супроводжується виникненням нового знання. У навчанні воно зумовлене віковими особливостями психічного розвитку дитини. Тому в реалізації інтегрованого підходу до структурування змісту шкільної освіти доцільніше шукати способи і дидактичні умови ефективного його впровадження, аніж протидіяти йому.

\section{Використані джерела}

[1] Державний стандарт базової середньої освіти. Затверджено постановою Кабінету Міністрів України від 30 вересня 2020 р., № 898 «Про деякі питання державних стандартів повної загальної середньої освіти». URL: https://zakon.rada.gov.ua/laws/show/898-2020-\%D0\%BF\#Text 
[2] Типова освітня програма для 5-9 класів закладів загальної середньої освіти. Затверджено наказом МОН України № 235 від 19.02.2021 p. URL: 602fd30bccb01131290234.pdf (mon.gov.ua)

[3] Концепція «Нова українська школа». Розпорядження Кабінету Міністрів України від 14.12.2016 р., № 988 «Про схвалення Концепції реалізації державної політики у сфері реформування загальної середньої освіти “Нова українська школа” на період до 2029 року». URL: Про схвалення Концепції реаліз... | від 14.12.2016 № 988-p (rada.gov.ua)

[4] Краевский, В.В, Лернер, И.Я. (ред). (1983). Теоретические основы содержания общего среднего образования. Москва.

[5] Леднев, В.С. (1991). Содержание образования: сущность, структура, перспективы. Москва.

[6] Савченко О.Я. (2011). Розвиток змісту початкової освіти в умовах Державного суверенітету України: методологічний, законодавчий, дидактичний аспекти. Початкова школа. № 8. 25-29.

[7] Tyler, R.W. (1949). Basic Principles of Curriculum and Instruction. Chicago: University of Chicago Press.

[8] Young, M. (2013). Overcoming the crisis in curriculum theory: A knowledge-based approach. Journal of Curriculum Studies. vol. 45, № 2, 101-118;

[9] Zongyi, Deng. (2015). Michael Young, knowledge and curriculum: an international dialogue. 2. vol.47, № 6, 723-732.

[10] Liashenko, O. (2019). Modernization of the general secondary education content as the basis of reforming the Ukrainian school. Education: Modern Discourses. 2, 126-133. https://doi.org/10.32405/2617-3107-2019-1-15

[11] Rybalko L., Topuzov O., Velychko L. (2020). Natural science education concept for sustainable development. Environmental, Technological, Social and Economic Matters (ICSF). Vol. 166. URL: https://ui.adsabs.harvard. edu/abs/2020E3SWC.16610030R/abstract

[12] Топузов О. М., Засєкіна Т. М. (2021). Науково-методичний супровід нової української школи. Вісник НАПН України. 3 (2), 1-7.

[13] European Commission /EACEA/ Eurydice, 2021. Recommended Annual Instruction Time in Full-time Compulsory Education in Europe - 2020/21. Eurydice - Facts and Figures. Luxembourg: Publications Office of the European Union. URL: Recommended annual instruction time in full-time compulsory education in Europe, 2020/21 - Publications Office of the EU (europa.eu)

\section{References}

[1] Derzhavnyi standart bazovoi serednoi osvity. Zatverdzheno postanovoiu Kabinetu Ministriv Ukrainy vid 30 veresnia 2020 r., № 898 «Pro deiaki pytannia derzhavnykh standartiv povnoi zahalnoi serednoi osvity». URL: https://zakon.rada.gov.ua/laws/show/898-2020-\%D0\%BF\#Text (in Ukrainian).

[2] Typova osvitnia prohrama dlia 5-9 klasiv zakladiv zahalnoi serednoi osvity. Zatverdzheno nakazom MON Ukrainy № 235 vid 19.02.2021 r. URL: 602fd30bccb01131290234.pdf (mon.gov.ua). (in Ukrainian).

[3] Kontseptsiia «Nova ukrainska shkola». Rozporiadzhennia Kabinetu Ministriv Ukrainy vid 14.12.2016 r., № 988 «Pro skhvalennia Kontseptsii realizatsii derzhavnoi polityky u sferi reformuvannia zahalnoi serednoi osvity "Nova ukrainska shkola” na period do 2029 roku». URL: Pro skhvalennia Kontseptsii realiz... | vid 14.12.2016 № 988-r (rada.gov.ua). (in Ukrainian).

[4] Kraevskiy, V.V, Lerner, I.YA. (red). (1983). Teoreticheskie osnovyi soderjaniya obschego srednego obrazovaniya. Moskva. (in Russian).

[5] Lednev, V.S. (1991). Soderjanie obrazovaniya: suschnost, struktura, perspektivyi. Moskva. (in Russian).

[6] Savchenko O. Ia. (2011). Rozvytok zmistu pochatkovoi osvity v umovakh Derzhavnoho suverenitetu Ukrainy: metodolohichnyi, zakonodavchyi, dydaktychnyi aspekty. Pochatkova shkola. № 8. 25-29. (in Ukrainian).

[7] Tyler, R.W. (1949). Basic Principles of Curriculum and Instruction. Chicago: University of Chicago Press. (in English).

[8] Young, M. (2013). Overcoming the crisis in curriculum theory: A knowledge-based approach. Journal of Curriculum Studies. vol. 45, № 2, 101-118. (in English).

[9] Zongyi, Deng. (2015). Michael Young, knowledge and curriculum: an international dialogue. Journal of Curriculum Studies. vol.47, № 6, 723-732. (in English).

[10] Liashenko, O. (2019). Modernization of the general secondary education content as the basis of reformng the Ukrainian school. Education: Modern Discourses. 2, 126-133. https://doi.org/10.32405/2617-3107-2019-1-15. (in English). 
[11] Rybalko L., Topuzov O., Velychko L. (2020). Natural science education concept for sustainable development. Environmental, Technological, Social and Economic Matters (ICSF). Vol. 166. URL: https://ui.adsabs.harvard. edu/abs/2020E3SWC.16610030R/abstract (in English).

[12] Topuzov O.M., Zasiekina T.M. (2021). Naukovo-metodychnyi suprovid novoi ukrainskoi shkoly. Visnyk NAPN Ukrainy. 3 (2), 1-7.

[13] European Commission /EACEA/ Eurydice, 2021. Recommended Annual Instruction Time in Full-time Compulsory Education in Europe - 2020/21. Eurydice - Facts and Figures. Luxembourg: Publications Office of the European Union. URL: Recommended annual instruction time in full-time compulsory education in Europe, 2020/21 - Publications Office of the EU (europa.eu)

Oleksandr Liashenko, Doctor of Pedagogical Sciences, Professor, Full Member of the National Academy of Educational Sciences of Ukraine, Academician-Secretary of the Department of General Secondary Education of the National Academy of Educational Sciences of Ukraine

Oleh Topuzov, Doctor of Pedagogical Sciences, Professor, Full Member of the National Academy of Educational Sciences of Ukraine, Vice President of the National Academy of Educational Sciences of Ukraine

\section{SCIENTIFIC SUPPORT FOR MODERNIZATIONS OF THE CONTENT OF BASIC SECONDARY EDUCATION: PROBLEMS AND CHALLENGES}

The article considers the scientific principles of updating and structuring the content of basic secondary education which form the basis of the recently adopted State Standard of Basic Secondary Education and developed Standard Educational Program for grades 5-9 of general secondary education. Based on the analysis of different approaches to the selection of the content of school education in different historical times, the research methodology is presented, which is based on the unity of personalityoriented, activity and competence-oriented approaches to learning as the foundation of the modern education paradigm. It is shown the difference between the structuring of the content of education based on the theory of content which is inherent in the national tradition and the theories of curriculum used in foreign educational practice. The competence-oriented principles of modernization of the content of education, which are the basis of the new Standard of Basic Secondary Education, are revealed, the expediency of transition from the knowledge paradigm of education to competence-oriented in the current update of the content of education is substantiated. It is emphasized that the current modernization of the content of education involves a wider use of a subject-integrated approach to the structuring of educational material, which takes into account the age characteristics of the mental development of a child.

Keywords: basic secondary education, modernization of educational content, theory of educational content, competence-oriented approach to learning, structuring of educational content, integration of knowledge. 